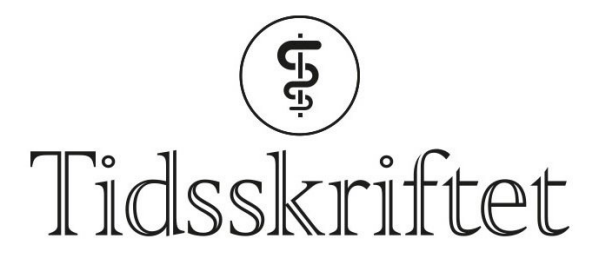

DEN NORSKE LEGEFORENING

\title{
Makroaneurisme i retina
}

MEDISINEN I BILDER

\section{ASTRID MEISTAD}

E-post:astridmeistad@gmail.com

Øyeavdelingen

Helse Nord-Trøndelag, Sykehuset Namsos

og

Orkdal Øye

Astrid Meistad er spesialist i øyesykdommer, avtalespesialist og tidligere overlege.

Forfatteren har fylt ut ICMJE-skjemaet og oppgir ingen interessekonflikter.

\section{AGATA FRAJDENBERG}

\section{$\emptyset$ yeavdelingen}

Helse Nord-Trøndelag, Sykehuset Namsos

og

Ögonkliniken

Universitetssjukhuset i Linköping

Agata Frajdenberg er dr.med., spesialist i øyesykdommer og overlege.

Forfatteren har fylt ut ICMJE-skjemaet og oppgir ingen interessekonflikter.

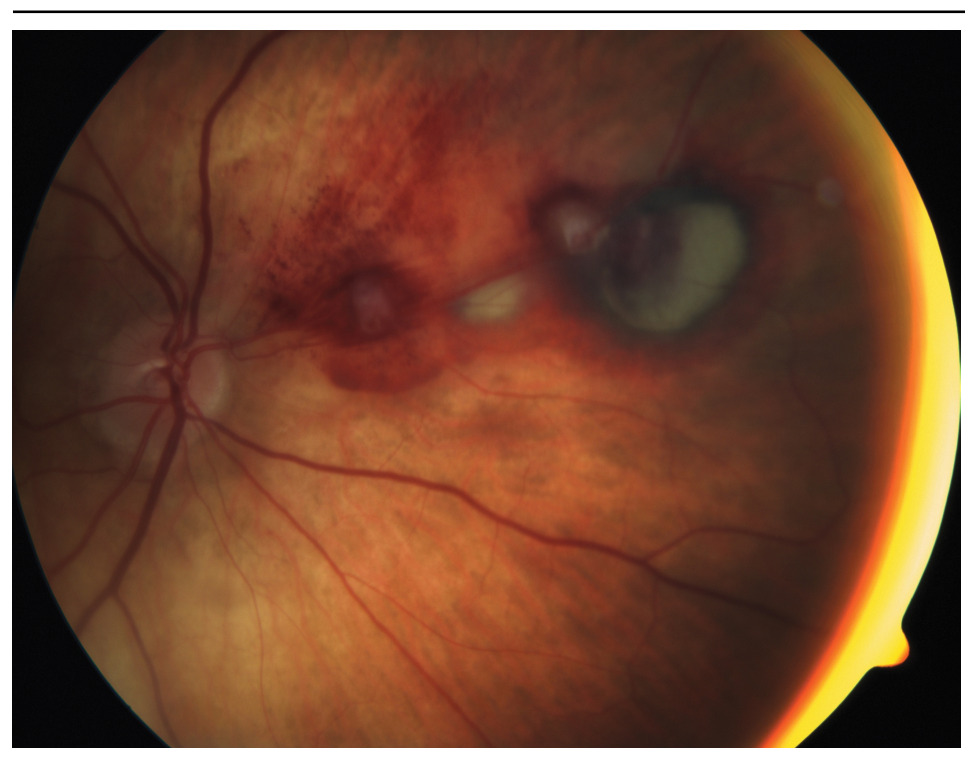

Bildet øverst er et fundusfotografi av høyre retina hvor man ser to makroaneurismer lokalisert langs øvre nasale kararkade. Det viser pre- og intraretinale blødninger samt grå områder som representerer subretinalt blod. Synsnervepapillen sees i bildets venstre del.

Bildet nederst er et korresponderende fluoresceinangiografibilde og viser avrundede områder med hyperfluorescens som representerer utposninger på arteriolen. Det sees også omkringliggende blokkering på grunn av blødning. 
En kvinne i 8o-årene hadde utviklet akutt skygge for høyre øye som hun beskrev som en «mørk ball». Hun var tidligere kataraktoperert med laserbehandling for etterstær og hadde aldersbetinget makuladegenerasjon. Hun brukte warfarin etter et hjerneslag med synsfeltdefekter som sekvele. Etter noen uker kom hun til oftalmoskopi og fluoresceinangiografi av retina. Korrigert visus var 0,5 på det aktuelle øyet. Siden lesjonene ikke påvirket makula, ble pasienten observert, og ved siste kontroll hadde hun visus o,5 og arrforandringer nasalt for papillen.

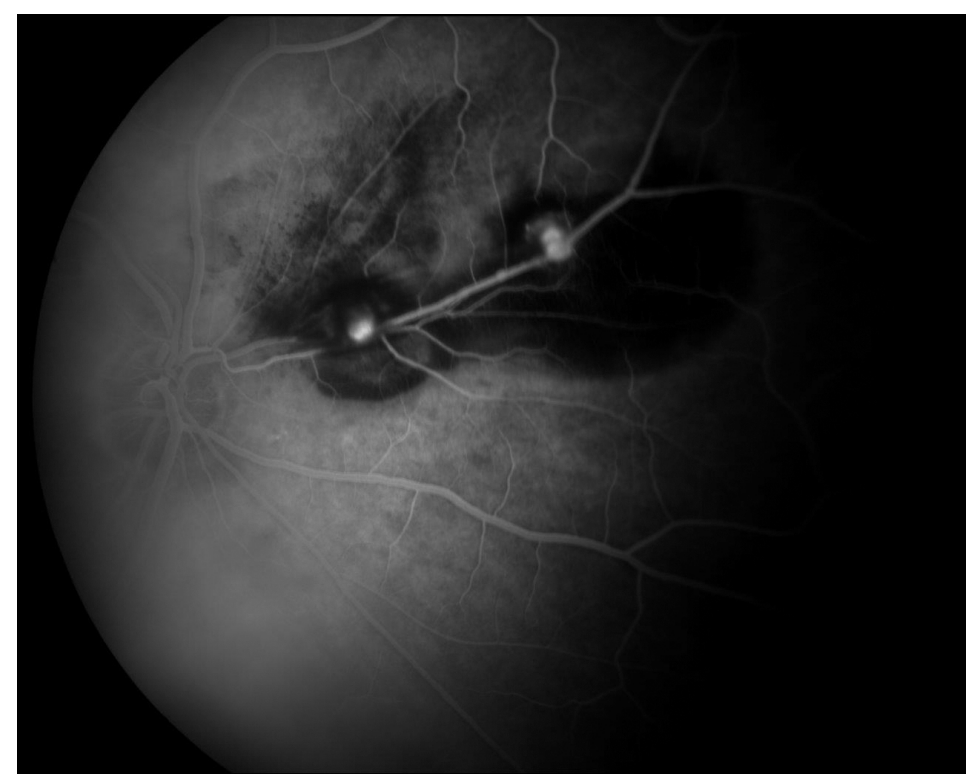

Makroaneurisme i retina er en sjelden tilstand. Anslått prevalens er 1 av 9 ooo øyne. Tilstanden oppstår helst hos hypertensive eldre kvinner og involverer i 90 \% av tilfellene kun ett øye (1). Den vanligste lokalisasjonen er øvre temporale kararkade. Aneurismen kan trombosere og tilbakedannes spontant, den kan rupturere og blø, eller den kan utvise kronisk lekkasje. Tilstanden kan behandles med laserkoagulasjon, alternativt med injeksjon av gass i glasslegemet for å forskyve subretinalt blod i makularegionen, eventuelt sammen med vevsplasminogenaktivator (tissue plasminogen activator, tPA).

Aneurismer i retina kan være mikro- eller makroaneurismer. Mikroaneurismene oppstår på kapillarnivå hos pasienter med diabetes eller andre mikrovaskulære tilstander, og sees som små punktformede røde lesjoner i retina. Bildet øverst er karakteristisk for makroaneurisme. Kjenner man utseendet, kan diagnosen stilles ved hjelp av enkel oftalmoskopi, uten utredning med fluoresceinangiografi.

LITTERATUR:

1. Kanski J, Bowling B. Kapittel 13. I: Clinical ophthalmology. Elsevier Saunders, 2011: 578-9.

Publisert: 23. november 2020. Tidsskr Nor Legeforen. DOI:10.4045/tidsskr.20.0469

Mottatt 21.5.2020, første revisjon innsendt 31.8.2020, godkjent 21.9.2020.

(C) Tidsskrift for Den norske legeforening 2020. Lastet ned fra tidsskriftet.no 